\title{
Lofts: Habitações para Além do Contexto Moderno
}

\author{
Lofts: Habitations For Beyond \\ The Modern Scene
}

Lofts: Habitaciones Más Allá Del Contexto Moderno
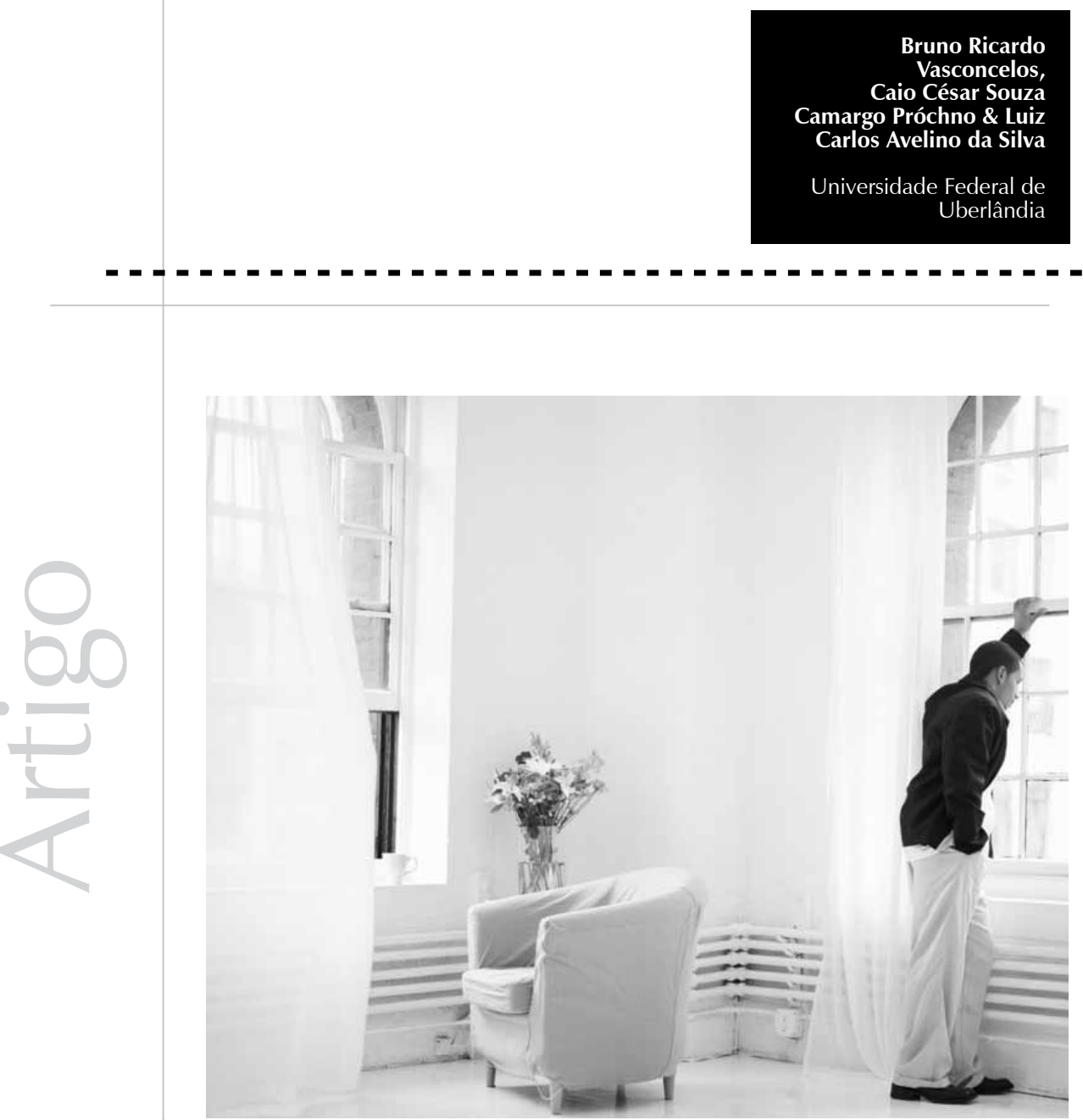
Resumo: Este artigo problematiza a habitação humana na contemporaneidade, tomando o loft como objeto de análise. Seu objetivo é dialogar, a partir de perspectivas críticas acerca das implicações que emergem da re-significação do espaço da casa, lócus das relações interpessoais contemporâneas. A partir de um referencial teórico que transita entre a psicanálise e a Sociologia, constata-se que as dinâmicas que se dão num contexto de transição, onde os modos de vida estão em metamorfose, assim como o seu contorno e seu substrato. E nesse contexto, o loft emerge como um símbolo da pós-modernidade, na transposição do espaço público para o privado, sendo um local onde tudo se vê e tudo se mostra, da liquidez das relações e da solidão

Palavras-chave: Habitação. Pós-modernidade. Psicanálise. Sociologia.

\begin{abstract}
Abstratct: This article discusses the human habitation in contemporary times, taking the loft as an object of analysis. Its objective is to dialogue, parting from critical perspectives about the implications that emerges of re-signification of the house's space, locus of the interpersonal contemporary relationships. Using theorical references that moves towards Psychoanalysis and Sociology, it is observed that the dynamics which develops on a transitional context, where the life patterns are in metamorphosis, as it's shape and it's essence. In this context, the loft emerges as a symbol of post-modernity, in transposition of public spaces to the private ones, locals where everything is seeing and everything shows itself, space of liquid relationships and loneliness
\end{abstract}

Keywords: Housing. Postmodernism. Psychoanalysis. Sociology

Resumen: Este artículo problematiza la vivienda humana en la contemporaneidad, tomando el loft como objeto de análisis. Su objetivo es dialogar, desde perspectivas críticas acerca de las implicaciones que emergen de la resignificación del espacio de la casa, locus de las relaciones interpersonales contemporáneas. Desde un referencial teórico que transita entre el Psicoanálisis y la Sociología, se constata que las dinámicas que se dan en un contexto de transición, donde los modos de vida están en metamorfosis, así como su contorno y su substrato. Y en ese contexto, el loft emerge como un símbolo de la post modernidad, en la transposición del espacio público para el privado, siendo un lugar donde todo se ve y todo se muestra, de la liquidez de las relaciones y de la soledad. Palabras clave: Vivienda. Post-modernidad. Psicoanálisis. Sociología.

Este ensaio tem o propósito de debruçar-se sobre o loft, e perscrutá-lo com lentes de autores originados da sociologia e da psicanálise, promovendo uma leitura de interface que permita desvendar os sentidos que emanam dessas construções. Seu objetivo é dialogar, a partir de perspectivas críticas, acerca das implicações que emergem da re-significação do espaço da casa, lócus das relações interpessoais contemporâneas.

Originalmente, os lofts eram galpões utilizados não como habitação e sim com intuitos trabalhistas, especificamente para estocagem. Concebidos a partir de um grande espaço aberto, isento de compartimentos ou divisórias, o que, aperfeiçoaria o espaço em sua funcionalidade. Alvo de políticas públicas que buscavam revitalizar a malha urbana; foram, a partir de 1970, repensados como moradias em Nova York. A partir de imbricados re-arranjos históricosociais que culminaram numa nova forma de concepção acerca do espaço habitacional, os lofts, foram destinados a servir como uma opção às tradicionais moradias, numa operação mais ampla que se proporia a resgatar um setor da cidade, esquecido pela especulação imobiliária, que agora se veria revigorado como cenário para novas áreas habitacionais, áreas cools.

Estruturalmente, este tipo de habitação herda do capitalismo uma dinâmica funcional de escoamento e vigilância panóptica, de forma que são reduzidas ao máximo, as existentes paredesque subdividam o espaço interno, além dos típicos pésdireitos altos que os caracterizam esteticamente. Oconceito de loft foi de fundamental importância num projeto de recodificação da malha urbana em alguns pontos de cidades americanas e européias pelas vantagens que apresentavam em relação aos custos, pois se localizavam em áreas ermas, até então destinadas exclusivamente a uma indústria agora retrógrada, pesada e cada vez mais incompatível com o contexto econômico contemporâneo. O intrigante, para nós, é que esse conceito habitacional entrou em voga. Possivelmente, são os lofts, as habitações que se estabelecem de forma mais estreita e concisa com o modo de vida contemporâneo, o mesmo modus vivendi que ainda novo varreu das passagens o Flaneur, de Baudelaire e Walter Benjamin. Faz-se necessário, antes de qualquer problematizarão do objeto, um pequeno adendo histórico. 
1 Prefiro nomear esse espaço de transições como hipermodernidade, na linha do que aponta Anthony Giddens em "Conseqüências da modernidade" (1991), em consonância com a tese de Baudrillard (1991), onde notamos que emergem inéditas nuances aos olhos do pesquisador, porém ainda revoltas a uma forte presença moderna, visto que, o capitalismo tardio ainda é o baluarte da sociedade contemporânea e a explicação das contradições inerentes a esse próprio modelo de produção se revela axiomática para elucidação de fenômenos que nos escapam e emergem nos contornos dos dias atuais. Não significa dizer que o pósmoderno se presta apenas como uma abstração teórica, mas de apontar que o que vivenciamos ainda não o é, e é próprio da lógica do capital, se rearranjar, metamorfoseandose a si próprio e transmutando os valores que constituiu a fim de legitimar-se como poder.
Na França do século XVII foi concebido o modelo habitacional mais influente até os dias de hoje. O cômodo, que deve ser entendido em um sentido análogo aos que podemos visualizar ainda hoje: no século XVII, a invenção do cômodo suscitou diretamente a invenção da família, num sentido "próximo" ao contemporâneo, tanto quanto a formação da subjetividade burguesa (Jameson, 2002), que irradia para fora de suas fronteiras claras influências que atingem todo o tecido social.

Esse cômodogerminal, intimamente relacionado ao emergir de uma individualidade que virá a suplantar os limites da família tradicional, é contemporaneamente confrontado com a "planta livre" de Le Corbusier, que o desafia enquanto categoria sintática, apresentando a possibilidade de habitar um espaço de forma inédita. O modelo da "planta livre", como Jameson (2002) a interpreta, pode muito bem ser visto como um novo cômodo otimizado, pode, contudo ser analisado como uma tentativa de transcender de vez tal categoria.

As seqüências de divisões tornam-se mais funcionais e a casa toma contornos específicos visando prover conforto e privacidade (palavra que só se justifica ao olharmos este período retrospectivamente) aos habitantes. As casas burguesas, diferentemente dos palácios nobres e dos cortiços, foram pensadas funcionalmente, com suas divisões mais reduzidas, porém cômodas, para resguardarem nesse cômodo a intimidade de uma individualidade cada vez mais pudica de seu morador. Não seria nenhum absurdo inferir à burguesia a invenção da casa segmentada em cômodos, e conseqüentemente, do modelo moderno de habitar essa casa; certo é que em momentos em que a história se vê numa grande transição ideológico-moral, modos de vida, antes tidos como cristalizados, começam a se metamorfosear.

Convém ressaltar que o traçado histórico dos modelos habitacionais não é propósito desta pesquisa; limitamo-nos aqui a conceber e analisar criticamente um espaço que se projeta como possível em termos da contemporaneidade; isso não quer dizer, contudo, que estamos "colocando" esse mesmo recorte em suspensão, negando as conexões que a ele são inerentes. É propósito claro aqui analisar a destituição do cômodo e não a trajetória histórica não linear que se deu para que o mesmo fosse concebido.

O conceito de moradia unifamiliar, torna-se cada vez mais inexpressivo quando discorremos sobre projetos de pós-modernidade, pois os fluxos que transpassam a ordem atual estão, cada vez mais, levando consigo o indivíduo enraizado, retirando desse o chão que se mostrava sólido. A pós-modernidade faz do chão uma vertigem e os planejamentos longínquos já não tem lugar na liquidez contemporânea. É intuito deste, analisar criticamente o loft a partir de suas interconexões com os modos de vida citadinos.

\section{Por um contexto}

É necessário, antes de tomar qualquer teorização como ponto de partida, esquadrinhar demarcações do contexto que envolve o objeto que pretendemos abordar. Os lofts estão circundados por uma "realidade" que se monta a partir da transição, fundada no movimento, tanto de corpos (anatomicamente adornados pelo consumo de massa), quanto de idéias e instituições. O loft, imerso nesse fluxo fugaz, muitas vezes nomeado como pós-moderno ${ }^{1}$, que rearranja de forma inédita a vida cotidiana dos indivíduos, cada vez mais bem definidos como transeuntes, se revela enquanto um objeto profícuo para análises.

Contemporaneamente os indivíduos em trânsito estão continuamente se deslocando do espaço público rumo a uma intimidade cada vez mais radicalizada; deslocam-se em direção a uma casa cada vez mais representativa de suas próprias "identidades em crise", visto que o espaço público está renegado às obrigações formais, não inspirando nos indivíduos que por ele transitam paixão alguma.

O espaço público, que Sennett (1998) diz estar morto é cada vez mais revogado ao trânsito, de 
forma que, vivenciamos a sua extinção como um espaço de permanência e de convívio. O que torna o contexto descrito ameaçador é o fato de que este era o lócus de onde o indivíduo retirava as suas mais significativas experiências que, por sua vez, seriam introjetadas nas dinâmicas da vida íntima. O espaço privado, até então, pautava-se por ser o espaço destinado ao resguardo, concernente ao descanso da exaustão vivenciada no espaço público. Contemporaneamente, a esfera íntima, o lar, é visto pelo transeunte como um fim em si mesmo e único, cada vez mais sedutor e, paradoxalmente, cada vez mais esvaziado de seu sentido; erodido em função de uma urbanização insensata das cidadesmercadorias, pelo colapso da articulação que se sabiamente se estabelecia entre o dentro e o fora.

Faz-se urgente nessa sociedade um diálogo mais estreito entre as Ciências Humanas e a Arquitetura, visto que o indivíduo moderno, cosmopolita, "existe num mundo totalmente fabricado por suas próprias forças, no interior de uma fantasia, numa cidade que é, concomitantemente, ordenada e fluída, metrópole do rígido caos" (Berman, 2008). O homem, nas suas relações sociais e psíquicas vê-se subjugado por suas próprias construções e tal empreendimento é de fundamental importância para a compreensão das dinâmicas que viemos a tratar. É por tal razão que julgamos pertinente um estudo, mesmo que breve, sobre a casa, o lar, um invólucro cada vez mais vazio e mais significativo para quem o habita.

Na mesma perspectiva de Sennett (1998), propomos um contexto contemporâneo em que a vida pública é vista com descrédito, como desinteressante, retratada muito bem pelo que Simmel (2006) denominou como o "ar blasé" dos passantes diante das rígidas estruturas da burocracia. A vida, em seu sentido público, não desperta em seus transeuntes paixão ou desejo de permanência, suscita apenas o cumprimento de uma obrigação formal; é fria, vazia, impessoal em demasia. A erosão de uma vida pública forte deforma, assim, as relações consideradas mais íntimas, que prendem o interesse sincero das pessoas. Tal deformação se expressa na mais íntima das relações: o amor físico (Sennett, 1998). Nessa obra Sennett mostra um paradoxo, que pode ser considerado um ponto chave para a compreensão da vida cotidiana na contemporaneidade. A evasão do espaço público tem como contraponto uma radicalização da esfera íntima; tanto do culto personalístico quanto do demasiado cuidado em relação ao espaço físico que envolve essas individualidades em constante transição.

A casa (entenda-se a casa em que reside o aparato psíquico e a casa em que reside o corpo) é o epicentro das experiências cotidianas. A vida íntima toma contornos cada vez mais relevantes, ao passo que essa mesma vida íntima, tão valorizada, encontrase em vertigem, visto que é de uma forte vida pública que é extraído o seu substrato. As leis que regem o "pós-moderno" são da ordem do capital, do minimalismo, em fina consonância com o narcisismo, de uma valorização exacerbada das experiências vivenciadas pela mais externa camada do eu, da ordem do "live for the moment", em negação aos projetos dispendiosos que se lançam a longo prazo, num culto à fugacidade, tanto das máscaras com as quais representamos quanto dos laços que amarramos com os outros.

Por razão de o público estar esvaziado, um modo de vida intimista e ensimesmado é suscitado, catalisado pelo consumo de massa que coage o indivíduo a se inserir como parte de um jogo de constantes e incansáveis mutações performáticas. O público carrega a sina do movimento, renegado à transitoriedade dos corpos que, submersos por essa dinâmica, não encontram lugar onde se faça possível a permanência. Tomado por vias expressas, largas avenidas, praças vazias, vidros translúcidos, fluxo de carros; os inter-relacionamentos se diluem na liquidez.

A desconstrução das paredes leva consigo a possibilidade de encontros e conversas mais íntimas; a privacidade, onde todos se vigiam 
involuntariamente, torna-se insustentável. Quando todos estão a se vigiar mutuamente, a sociabilidade se esvai e o silêncio é a única forma de proteção (Sennett, 1998). O som da cidade se resume ao barulho dos burburinhos que Goethe (1999), em suas andanças, captava. Os encontros no espaço público se resumiram a esbarrões que atrasam o fluxo dos pedestres e carregam consigo a fria polidez da impessoalidade, munida de diversas máscaras sobrepostas que evitam o fardo de se aproximar do outro e ter de estabelecer com o mesmo um elo; revelador de nossa privacidade. O público, por mais fantasmagórico que pareça, imprime marcas irreparáveis no modo de vida intimo.

Jameson (2002) observa que o apetite voraz, instaurado na "pós-modernidade", pela arquitetura é um apetite pela fotografia; um apetite que se faz por uma imagem provisória. O termo provisório, similar aos difundidos termos: transitoriedade, liquidez, fugacidade, tais quais parametrados pela obra de Sennett (1998) são axiomáticos para a compreensão do tema que se estuda. A instauração, pelo modo de produção capitalista, de falsas necessidades impossíveis de serem saciadas, faz com que o contemporâneo esteja em uma dinâmica constante de construção, demolição, reforma e reconstrução sem nenhuma ordem pré-estabelecida e sem vistas à conclusão. As estruturas alvos dessas transformações não se limitam às rígidas paredes que envolvem os lares, as empresas, os clubes, etc., mas se enveredam para o corpo anatômico, para as máscaras identitárias, modos de vida; ou seja, tudo e todos estão em inércia, nesse incessante movimento de recodificação.

A sensação que permeia o viver contemporâneo é de uma "confusão", que não delimita bem o que é dentro e fora, o que é eu e outro, o que é sexual e erótico, o que é real e o que não o é. Jameson (2002) exemplifica bem essa sensação ao relatar uma entrevista feita com o arquiteto norte-americano Frank Gehry, que construiu sua própria residência mesclando uma casa remanescente às camadas de uma nova casa, uma sobreposta à outra com materiais modernos, em simbiose com os antigos, onde fachada e interior se inundam e dão ao todo uma aparência de estranhamento. Na casa de Gehry os ambientes interiores se juntam em um diálogo com os exteriores, de forma que o arquiteto relata a sua experiência cotidiana como um pouco confusa, sendo que sentia um certo caos na maneira como tentava se organizar para nela habitar, tendo tudo isso relação com o fato de não saber se ela havia ou não sido efetivamente concluída. (Jameson, 2002)

Jameson (2002) retrata a casa de Gehry como uma casa de indiferenciação contínua, de forma que no invólucro não há como distinguir cômodos, pelo modo como estão dispostos e pela grande porção aberta ou envidraçada, causando no visitante uma emoção comparável a um mal-estar, gerado pelo não se situar, estar em suspensão. O novo espaço pós-moderno suscita assim um paradoxo: ao passo que as ruas estão em iminência de se esvaírem em prol de vias expressas que possam acelerar os fluxos, a casa e a intimidade não podem estar às avessas a tal transformação (Jameson, 2002). A casa se encontra nessa transição, entre cômodos e lacunas, entre paredes e vãos, de modo que nossos corpos a habitam com desconforto ou deleite. Na incessante tentativa de abandonar velhos hábitos e percepções do que é externo ou interno, sentindo-se profundamente saudoso da privacidade inspirada pelo modelo habitacional burguês, notamos o quão árduo se torna vivenciar a transição. Descolado da sólida conjectura familiar moderna, deslocado das afetividades eróticas e dos projetos que se projetam a longo prazo; estamos, como aponta Jameson (2002), situados numa desordem de ambiente no qual as pessoas nem as coisas têm mais seu lugar.

É notório que estamos sobre uma inédita produção de signos, insaciável, fomentada pelo consumo de massa, que sucumbe a si mesmo para se gerar mais forte e mais ávido. Berman (2008) aponta para um pesar, endêmico à vida moderna, típico de ver todas as construções virem abaixo para darem lugar a um novo projeto, um novo modelo. Esse constante 
"transformar" atinge a arquitetura, mas imprime marcas significativas nos modos de vida, na consciência subjetiva, na afetividade cosmopolita e no substrato que tenciona a função do sujeito. Ao citar as obras de Moses, Berman (2008) aponta para a edificação de um espaço público radicalmente diferente de tudo o que já existia em qualquer parte, pois o espaço carregava em si uma "limpidez assombrosa" de espaço e forma. Essa limpidez lacunar pressupõe uma liberdade de movimentos ao corpo, até então inexistente nas construções empreendidas pelo homem. Essa possibilidade de deslocamento, inerente a um espaço físico ilimitado, sem fronteiras, também incute na experiência uma sensação de perda e de uma amplidão, por demais vazias e, acima de tudo um estranhamento quanto ao fato de que não há mais como estar escondido do olhar alheio. É como se estivéssemos nus diante de uma platéia inexpressiva.

\section{Entrando na porta do Loft}

Cabe mais uma nota histórica. Na modernidade, as grandes cidades passaram a abrir vias expressas, influenciadas pelos boulevares de Haussman, cindindo seu próprio cerne, cerceando o tamanho das habitações e retirando as mesmas das regiões centrais, varrendo do centro citadino a sujeira do proletariado e sua mania insurreicionista de montar barricadas. Neste contexto, o centro da cidade foi destinado ao domínio público, tanto da governança estatal, quanto das escolas e centros culturais, das empresas e principalmente, destina-se ao fluxo de homens e automóveis.

Neste quadro, o movimento, que é fundamental para o capitalismo, é asfixiado por uma arquitetura claustrofóbica, de ruelas e bairros "apertados", que podem lhe conter. É preciso dar vazão ao movimento e expurgar dos centros urbanos as classes proletárias com seus cortiços, que mais se assemelham às bricolagens perigosas. Urge, pois, uma necessidade de assepsia, de limpar o centro, horizontalizá-lo. Os bairros vão se fixando nas margens e, num caminhar histórico não cronológico nem linear, vão se esvaindo. Suas dinâmicas de cores vivas, de burburinhos, de vizinhanças, de bares e vigilâncias, vão se limitando pelo próprio espaço interno da casa, da família, do refúgio ao extenuante mundo do trabalho.

Neste contexto, o indivíduo, apartado da espontaneidade do espaço efetivamente público, ao retornar para a casa, uma espécie de retorno metafórico ao útero materno, busca o conforto e o calor que as burocracias desprezam, que lhe são negados na intimidade do lar. Porém, é preciso atenção para o que está posto no texto: a erosão de uma forte vida pública deforma a estrutura da vida privada, imprimindo marcas profundas inclusive na mais intima das relações: o amor físico.

Le Corbusier, com a planta livre, embrião da concepção contemporânea de loft, desejou em seu íntimo a morte da cidade, numa fixação estremada pelos planos horizontais e pela liberdade de movimentos que ela implica. Apoiava a idéia de construção das viasexpressas, símbolo da insaciável movimentação e fluxo da pós-modernidade, renegando o papel do ator urbano ao papel de transeunte, frente à paisagem fugidia das cidades que recortam os bairros, desfragmentando-os e dificultando a possibilidade de interrelacionamentos cotidianos que fujam à impessoalidade. Só podemos experimentar os espaços idealizados por Le Corbusier, influência clara para Oscar Niemayer, arquiteto que projetou Brasília, munidos de carros potentes e fálicos. Já que rodovia e cidade não se coadunam, necessitamos matar a cidade (Berman, 2008) para dar lugar ao movimento dos corpos.

O "Flaneur" benjaminiano, que não se quer deixar ser engolfado pelo movimento opaco da massa, pelo devir alienante dessa homogeneidade, se vê, nesse contexto, cercado por materiais rijos, frios e escorregadios, onde é impossível se fincar firmemente para contemplar o andar da massa. O Flaneur deixa então se imiscuir na experiência atrofiada 
Para Le Corbusier a qualidade da circulação interior é a virtude biológica da

obra, organização do corpo construído, em verdade, ligado à razão de ser do edifício. Ainda em Corbusier, o mesmo aponta para uma tradição arquitetônica que deseja nos mostrar o homem nu se vestindo

(tal alegoria será essencial para o estudo um pouco mais a frente), se cercando de instrumentos e de objetos, de quartos mobiliados, de uma casa, satisfazendo razoavelmente o que lhe é indispensável. da massa. O choque, ainda pensando com Benjamin, já em vias de deixar de provocar traumas, passa a deslizar num corpo sem atrito, liso, sem causar ali, estranhamento algum. $\mathrm{O}$ então Flaneur já não o é mais. Não passa agora de um mero transeunte abobalhado com a grandeza do cenário que o cerca, respirando o ar blasé da veloz contemporaneidade. Nesse passo alienante, caminha rumo ao loft.

Walter Benjamin (1985) sabe muito bem da sua condição. Sabe que o destino daquele que flana pelo cenário sem querer ser por ele consumido, é justamente esse, ser dialeticamente absorvido, e essa imersão se dá pela avassaladora paixão que o invade: admirar a massa em seu devir. Baudelaire, o último Flaneur, não se recusaria também a esse trágico fim. Resta ao que sucumbiu à sedução da massa, o adorno do capital, a regressão dos sentidos e, a regressão crítica.

Para Le Corbusier a qualidade da circulação interior é a virtude biológica da obra, organização do corpo construído, em verdade, ligado à razão de ser do edifício. Ainda em Corbusier, o mesmo aponta para uma tradição arquitetônica que deseja nos mostrar o homem nu se vestindo (tal alegoria será essencial para o estudo um pouco mais a frente), se cercando de instrumentos e de objetos, de quartos mobiliados, de uma casa, satisfazendo razoavelmente o que lhe é indispensável. Le Corbusier precisa de uma marreta para destroçar as paredes que estiverem a sua frente, ávido pela liberdade de movimento. Em um explícito strip-tease se mune de vidraças, vãos, cortinas e biombos numa recusa ferrenha a tudo que é sólido, estático e capaz de obstruir a transição dos corpos. A frase do autor é sintomática: "a vida... só desabrochará onde encontrar equivalência arquitetônica e a aeração". Le Corbusier é a voz pós-moderna e o seu slogan perfeito, porém precisamos problematizar seus ideais, mostrando o quão escorregadias e paradoxais são as suas concepções, prometendo algo não passível de ser materializado, pois no bojo do contexto a arquitetura da planta-livre é uma falácia.
Está claro que a intimidade, sem experiência e vivência pública é refratada e "incompleta", de modo que o indivíduo, ávido por orgasmos múltiplos e satisfações efêmeras intensas, dirige-se a uma intimidade radicalizada em seus limites, em busca do que não mais pode ser satisfeito no lócus público. O pós-moderno sublinha na vida cotidiana individual uma valorização extremada dos aspectos privados: encoraja o "amor", a casa, o calor, os intensos sentimentos afetivos e a privacidade. O pósmoderno instila no indivíduo a possibilidade de uma vida que se define pela intimidade, onde o instante, os momentos, os prazeres fugazes são as palavras de ordem. Mas é, para nós, claro que todas essas idéias, após serem devidamente ruminadas, soam sem sentido, pois ao passo que o pós-moderno suscita esse sentimento, viabiliza seu avesso, de forma que a intimidade está por ser produto de um espaço público fantasmagórico, cindida. Os planejamentos longínquos estão em crise, a afetividade, imersa na impossibilidade de elaborar "raízes" sólidas, se lançou a uma sexualidade narcísica anti-erótica, que não mais compartilha da experiência de desfragmentação da alteridade e que, em contrapartida, se enfastia nas próprias genitálias em close e na satisfação de orgasmos cada vez menores, porém cada vez mais famintos. De certa forma, a publicidade pós-moderna, nos impõe um solo repleto de armadilhas.

Essas questões nos lançam a uma complexa rede de significados: o outro, essencial para a satisfação das necessidades impostas pelo "eu", não pode sobrecarregar este mesmo "eu" de peso, não pode estancar o fluxo que a própria modernidade exige de seus hóspedes. Ele deve contemplar as necessidades narcísicas desse "eu" mutilado, impostas pelo consumo de massa. Na fluidez de tudo, na eminência de intimidades impossíveis, na impossibilidade de serem estabelecidos laços de significação verdadeiramente erótica, a arquitetura do loft é o retrato da experiência cotidiana em pós-modernidade. O loft é a materialização da fluidez, da privacidade impossível, da 
casa da solidão. Com seu pé direito alto, e sua liberdade de movimentos, é o espaço perfeito onde as representações que se estabelecem no drama pós-moderno podem ser contempladas a partir de todos os ângulos sem nenhum empecilho de paredes, ao passo que a ausência das mesmas protege o sujeito de carregar o fardo simbolizado pelo peso do longo prazo e da solidez, aquilo que se chama "o outro".

\section{Não há fresta, não há espreita: o ver e o ser visto}

A partir do que foi posto nas seções precedentes, podemos imaginar o espaço do loft como um espaço amplo não apenas como dilatação do espaço geométrico, mas como ampliação de um "espaço subjetivo". Um espaço sem restrições a tão falada liberdade de movimentos; que está como já observado, em fina sintonia com as conjecturas individuais e subjetivas de um espaço híper-real, que o envolve e as habitações em geral: o espaço social em geração reconhecido como "pósmoderno". Destituído de separações, esse espaço exige de nós uma imersão mais íntima, que revele, mais profundamente, suas nuances.

Visto de dentro, causa-nos certa sensação de leveza; tudo está disposto de modo livre, quase que em suspensão. Nenhum objeto está condicionado a uma rigidez inflexível, e de qualquer ponto referencial, temos visão panorâmica do todo, tudo está exposto e, tudo em nós, enquanto estrangeiro no espaço, está da mesma forma, desnudado. Durante o dia, a própria luz não encontra restrições. As "janelas" foram ampliadas de forma que nada fique sombreado; a sensação de leveza e clareza inebria nossos sentidos para o que, talvez, esse deleite estético esteja a encobrir.

O olho, no loft, foi "optimizado". Em contrapartida, o ser visto por todos os ângulos é condição sine qua non deste modelo habitacional. Estão todos nus, diante dos olhares fotográficos do outro, o que, por sua vez, está em consonância com a atitude narcísica observada em contemporaneidade em relação à afetividade e aos sexos. $\mathrm{O}$ outro estrangeiro e a casa são objetos que devem contemplar aprovativamente as representações individuais do corpo. Urge no indivíduo uma força: qualquer parede deve ser destroçada com uma marreta.

O narcisismo, que clama por aprovação da imagem que projeta, não precisa de settings, pois não representa uma personagem erigida pelo diretor, mas o que for preciso e o que lhe convir, trocando incansavelmente de máscaras num movimento infinito que retira dessas uma verdade provisória e inquestionável e anseia da próxima uma verdade ainda maior numa recusa ferrenha à máscara anterior. Todas as máscaras devem ser ovacionadas pelo outro e as paredes dificultam ao possível espectador a contemplação das performances que o "eu" performativamente estabelece.

O loft, é o lugar destas performances justamente pelo fato já observado de que o indivíduo contemporâneo foi violentamente desarraigado de suas bases tradicionais, foi descolado de seu espaço original pela força sutil do capitalismo tardio, lançado em uma condição pós-moderna, destinado a viver uma vida líquida em todas as suas esferas. A vida profissional está à mercê dos instáveis movimentos flutuantes de capital, e, absorta pela primazia econômica. A vida afetiva encontra-se sem lugar.

Sem a perspectiva de amores longínquos, envolto por relações sexuais frívolas, o erotismo vai se esvaindo na impossibilidade do compartilhar signos, deixando-se entregar num jogo esportivo de profusão sexual e publicitária (imagética), explícita e invasiva. Este panorama está a nos retratar uma experiência cotidiana regida por uma força superior: a solidão. Estaríamos, pois, diante de uma transmutação sócio-cultural, vivenciando peremptoriamente o emergir do novo?

As reflexões sobre esse indivíduo caminham em vias iguais, duas forças convergentes: a "desubstancialização" do homem urbano e 
a profusão, por diversos meios midiáticos, de signos eróticos que enfatizam as relações afetivo-sexuais, as estabelecidas com o próprio corpo e, porque não, com a própria casa. A "desubstancializaçao" do sujeito evoca uma vida erótica em colapso que tem como cenário um modo de vida que imprime na experiência individual uma falta de lugar. $\mathrm{O}$ "eu", que perdeu o espaço público como lócus de permanência, se voltou para sua casa e a construiu como um reflexo de si: um loft, um reflexo fantasmático, insustentável, capaz de prometer ao corpo uma imagem de plena satisfação, sem saber que esse mesmo corpo não se deixa preencher-se.

Num diálogo com Foucault (1999) é possível estabelecermos uma ponte com o conceito de panóptico. O panóptico enquanto pequenos teatros, em que cada ator está sozinho, perfeitamente individualizado e constantemente visível. O dispositivo panóptico, nesta analogia, não pode ser tomado ao pé da letra, pois Foucault (1999) faz questão em deixar claro o fato de que nesse espaço o vigia não é visto pelo "detento", nem mesmo é sabido pelo recluso quando suas performances estão sob o olhar vigilante, causando uma sensação de monitoramento constante. O loft, num primeiro sentido, é um panóptico, pois todas as ações estabelecidas no microcosmo da casa estão sob o voraz olhar do outro e, estar sob o olhar alheio é ser coagido inconscientemente ou não.

As crianças em tempo de reconheceremse a si mesmas a partir de seus órgãos íntimos estão sempre a mudar de canal em horários inapropriados em busca de algo excitante, ou de folhear revistas em locais escuros e escondidos; os namorados, no auge das paixões e, na impossibilidade de se trancafiarem em um quarto, se saciam às escondidas pela sala ou pelos cantos. Entre outros tantos exemplos possíveis elencamos estes, para comentar o fato de que as construções arquitetônicas conhecidas agora enquanto lofts servem como minas à vida subjetiva individual; tudo está desvelado e nada agora se deixa esconder nas sombras.
Tudo está nu diante do olhar, formando assim, uma espécie (leia-se com muitas aspas) de "panóptico habitacional" ${ }^{2}$, que vai, gradativamente minando as transgressões aos pequenos interditos, essenciais para a construção de individualidades verdadeiramente autônomas. Utilizamo-nos de Foucault novamente: "A visibilidade é uma armadilha" (Foucault, 1999, p. 191). O espaço do loft implode o espaço panóptico, de modo que proclama o fim de perspectivas unívocas.

A planta livre, de Le Corbusier, é um exemplo condicional de que a habitação vista em seu sentido histórico, é também um reflexo das predisposições subjetivas do sujeito, ou seja, a casa (estrutura sólida que resguarda a vida das ameaças do sócius) espelha um reflexo da própria constituição do indivíduo, imerso em sua respectiva ordem subjetiva e histórica. Le Corbusier idealizou a casa de Narciso; o "panóptico habitacional" do espetáculo onde o que importa é ver e ser visto através dos biombos, vidraças, espelhos e vãos. Em outras palavras, a "planta livre" ou loft é a casa onde tudo se entrega ao voyeurismo.

Seguindo a trilha deixada por Benjamin (1985), o quarto burguês, mais que nome, tem porta, e cada porta deixa ressoar no vão do corredor, extinto pelo loft, a frase: 'Não tens nada a fazer aqui'. Em cada cômodo, um segredo repousa diante da porta e diante de cada porta a questão ecoa sempre querendo dizer: 'O que quer você, ver através de mim?' Tudo no cômodo burguês está revestido por uma espessa camada de verniz chamada segredo. Como Benjamin (1985), sabiamente aponta: a casa não quer ninguém ali, ela está repleta de rastros deixados pelos habitantes; a casa é uma casa de desejo, uma casa desejante, suja pelos rastros de quem ali se deixa marcar. Enfim, a casa burguesa está cercada por rastros obscuros. Na assepsia do loft, o rastro e o vestígio se foram; após cada banquete escópico, os rastros e vestígios se diluem rapidamente como aquarela fresca em superfícies sem atrito.

Sheebart e Bauhaus (in As Passagens, Benjamin, 2009) extinguiram a sujeira dos rastros ao 
2 Por panóptico habitacional, estamos nos referindo a uma forma de ocupar a casa que não mais se assemelhe à que designamos como moderna. Estamos diante de uma residência que clama a todo momento pelo olhar da alteridade, que chama pelo olhar do outro, tanto para si mesma, quanto para o que ali adentra, porém de maneira avessa ao panóptico foucaultiano, há nas instituições totais de Foucault, um olhar vigilante que não se deixa ser visto pelo cárcere, No loft essa hierarquia escópica é destruída, tudo vê e é visto sem pudor.

3 Trecho extraído da obra "As Passagens" de Benjamin. Em suas extensas coletas de material, Haussman

é uma voz cara a

Benjamin, uma voz que quando resgatada suscita a reconstrução da malha urbana parisiense, trazendo consigo a extinção das vivas e efervescentes passagens. inaugurarem uma arquitetura rígida e fria, do aço e do vidro. Nessas superfícies brilhantes, cada toque se esvai. Por ali, é difícil deixar rastros, mas fácil se ver refletido. A casa marcada por tais materiais frios reverbera na massa não mais afetada pelo choque traumático, uma atração apaixonante. A nova casa, o loft, traduz dialeticamente o desejo alienado do corpo contemporâneo. O corpo reclama poder para o olho faminto, inofensivo no sócius. O corpo transitório quer ser visto, contemplado e admirado como o centro que é no seu frio mundo; quer que cada nuance sua seja esquadrinhada pelo olhar alheio, olhar que vê por todas as perspectivas e que agora quer tocar.

O corpo-fetiche no loft realiza sua operação espetacular quase perfeita, quer o banquete escópico, quer dominar pelo olho fálico e quer se apreciar em ato, em performance. Saciado o olho, aço e vidro apagam o outro que se foi como aquarela, que, lançada em superfície lisa, rapidamente se esvai sem deixar cor. Sheebart ilustra bem essa questão, falando pelas mãos de Benjamin (1985) ao proclamar que "O novo ambiente de vidro mudará completamente o homem" (Benjamin, 1985, p. 118).

Como Haussman ${ }^{3}$, o movimento sinuoso do capital quer fazer da cidade um projetoescorregador; um lugar onde a permanência se reduza ao espaço dos bares ou cafés; não as ruas. Haussman quer abrir com uma pá as veias da cidade, quer artérias cada vez mais largas. Nos boulevares parisienses, Baudrillard (1991) lança Las Vegas; num fluxo, que de tão intenso implodiu seus referenciais, se é que um dia verdadeiramente os teve. Um fluxo hiper-real, num jogo de simulacros em constante simulação.

Como aponta Freud (1905/1996), o que nos difere de nossos ancestrais, afetivamente, é que a nossa ênfase não está mais ligada à própria pulsão sexual, e sim no objeto desta mesma pulsão. De certa forma, estamos com os pés fincados, contemporaneamente, numa sexualidade fetichista. Excitamo-nos ao observarmos a cópula empreendida por outros, haja vista o sucesso dos sites pornográficos que bombardeiam nosso campo ótico com um ato sexual sem gozo, meramente esportivo, sempre sob um close glacial. Excitamo-nos ao contemplar a exposição das genitálias destes outros, de forma que não é errôneo caracterizar a sociedade do nosso tempo como uma sociedade voyeur. Excitamo-nos, mas num contexto completamente outro, de cunho explicitamente sexual e anti-erótico. Como bem ilustra Kierkegaard (2010) "A simples posse é algo vulgar... Que prazer pode oferecer o amor se não contém, em si mesmo, o abandono absoluto de uma das partes" (p.56).

O referencial é um algo em crise, em dissolução. O loft é o microcosmo por onde se dão todas essas dinâmicas. Apoiado em Benjamin, cremos que há no loft, uma arquitetura sem aura, fruto de uma reprodução meramente técnica que pode vir a ser repetida ad Infinitum, se destituindo de seu substrato. $\mathrm{O}$ ver, derivação do tocar, é imprescindível à existência de humanidade, pois é a partir da excitação libidinosa que o objeto sexual se torna alvo do olhar. Aí entra o jogo de mostrar ou esconder, adornar ou sublinhar o que está em realce, o que atrai o olhar, ao mesmo passo que, em contrapartida, se camufla o que pode obstruir o objeto de desejo. O jogo coloca-nos em palco e o olhar curioso deseja revelar o que está encoberto no corpo do outro.

\section{O substrato desse espaço}

O que habita esse espaço em transição? Que indivíduos, que arranjos familiares, o que de fato preenche esse espaço lacunar? Pretendese aqui estabelecer um breve diálogo com Prost (1992). Antes convém ressaltar qual a intenção em analisar o retrato hipotético da família: Giddens (1991) em "As Conseqüências da Modernidade" aponta para a questão conceitual da pós-modernidade, incluindo nos debates a questão relativa à possibilidade de existência de pós-modernidade sem a condição de uma alteração nas bases dos modos de produção, ou seja, é possível estarmos em pós-modernidade, quando ainda estamos 
profundamente arraigados no signo maior da modernidade: o capitalismo?

Giddens (1991), porém, enfatiza as nuances pós-modernas que emergem de uma estrutura moderna, nuances como a problemática do espaço público, a nova ordem "flexível" do trabalho, as novas organizações familiares, a individualidade/subjetividade, as imbricadas análises acerca do gênero, que justificam o uso do termo modernidade radicalizada. Visto que vivenciamos a transição, faz sentido dizer que estamos percebendo tudo se dissolver e se remontar em novas formatações, às vezes nem tão novas assim, pelo motivo de ainda não nos encontrarmos, de fato, em pós-modernidade. Com isso podemos nos situar no contexto em que a família contemporânea está imersa.

Em modernidade, como afirma Prost (1992), a família perdeu suas funções públicas passando a ter apenas funções privadas. Assim, a família vê sua própria força se diluir: "sua privatização é uma desinstitucionalização" (p.53). As famílias perdem sua função educacional, elucidativa em relação ao futuro dos filhos e a função pública se desfaz cada vez mais. Tais funções são delegadas à escola, que não apenas transmite saber como educa, "ama" e suporta as crises típicas da infância e da adolescência.

Prost (1992) nos mostra que a educação tem como sentido o lócus público e, como a família perdeu seu viés público (visto que as profissões hereditárias se foram junto com a imagem do paterfamilias) ao se tornar puramente privada e deixou de ser plenamente educativa. A família, ao invés de uma instituição estrutural passou a ser identificada por Prost como "um simples ponto de encontro de vidas privadas"

O que nos parece paradoxal é que as famílias modernas geram em seu seio sua própria dissolução. Na medida em que os cômodos, inicialmente burgueses e posteriormente disseminados por "toda a sociedade", segmentados em compartimentos, foram se constituindo, a privacidade individual foi ganhando terreno, de modo que cada membro da família teve em si instilado um desejo por seu espaço próprio. Cada membro se tornava assim, um indivíduo pleno, cerceado pelas paredes que suscitam que ali reina uma intimidade particular, ímpar, singular a todas as outras. A família gerou a individualidade a partir de cômodos com paredes espessas, claro que, em consonância com o Estado capitalista burguês, que, a partir das bases desta mesma individualidade, sedimentou os princípios do individualismo enquanto condição para uma sociedade imersa no consumo de massa.

Estamos fazendo um desenho, o desenho da família que instala em si, o próprio colapso. A família criou no seu ventre o ser individual, educado na escola, assistindo pela TV à morte simbólica do pai. $\mathrm{O}$ impulso moderno da independência individual, contemporaneamente se deparou com nuances de pós-modernidade que instilam nesse mesmo indivíduo a impossibilidade de se fixar, a urgência da fluidez.

Em meados do século XX o casamento fundamentado nas bases do amor romântico ganhou força. As famílias como gestoras matrimoniais gradativamente foram desaparecendo e o feminismo e suas conquistas alteraram profundamente as dinâmicas da vida cotidiana. Prost (1992) assume: é preciso amor, ao invés de matrimônio, para legitimar a sexualidade. A partir deste amor, gerado entre intimidades distintas e bem delineadas, surgiu a necessidade de cópula habitacional.

Contemporaneamente, a coabitação suplanta a idéia de matrimônio por um motivo simples: envoltos pela lógica pós-moderna não há possibilidade de estabelecer horizontes longínquos, de forma que nos colocamos ao lado de Prost quando o mesmo afirma que casar é inscrever a vida num projeto de coabitação que se contenta com um presente intenso e desconfia do futuro. Casar está ligado a cercear o companheiro e a si mesmo e é, de certa forma, se colocar diante do fluxo.

A afirmação fervorosa da vida privada de cada indivíduo corrói internamente a instituição 
matrimonial, moldando novos modos de conduta, novos cânones afetivos e, em contrapartida gerando em seu cerne, crises espirais, inéditas e dignas do nosso tempo. A família, uma das remanescentes forças modernas, paradoxalmente, deu brechas para o surgimento de um modo de vida urbano que se define pela busca, e, pela satisfação de impulsos fugazes impossíveis de serem satisfeitos, pois quando se atinge o orgasmo o que se anseia já é outra coisa que não aquela que divide o leito. (Prost, 1992)

O desenho parcial está terminando, e a partir dele podemos continuar o que iniciamos anteriormente. A emergência do indivíduo que tem na pós-modernidade seu lugar é a emergência de um indivíduo cada vez mais desprovido de lugar, desamparado. Podemos aqui regressar ao loft, esse espaço tão pertinente ao nosso tempo, que se apresenta como palco para as performances do corpo individual e dá à platéia possibilidades novas de contemplar esse mesmo corpo, ao mesmo tempo em que por ele é contemplado.

O loft é essencialmente a habitação pósmoderna. É a fresta e é a nuance que nos permite ver o pós-moderno. O indivíduo, criado pelos cômodos segmentados que permitiam a cada um o cultivo de uma intimidade particular, criou seu próprio hiper-cômodo capaz de envolver sua mega necessidade de uma hiper vida privada. O indivíduo pós-moderno está ávido por relações cada vez mais intensas e cada vez mais rápidas, menos exigentes, mais flexíveis e impossíveis.

É essa impossibilidade que desloca a vida pós-moderna num sentimento de angústia contínua. O capital e a cultura contemporânea criam um ciclo de necessidades que não se saciam, pois ao se saciarem instilam novas necessidades impossíveis. Conceber o ser humano como aquele que se designa pela falta é coerente, porém, estamos diante de um modo de vida que intensificou tal falta a um patamar angustiante, ao invés de se utilizar desta falta como catalisador da experiência intra-mundana. $\mathrm{O}$ indivíduo ultrapassou a família e, agora se esforça a fim de ultrapassar a si mesmo. É um modo de vida radicalmente urbano e o seu lugar é a privacidade do loft, onde se deposita o vazio vivenciado no espaço público.

\section{Hiper-cômodo}

Cabe nesta seção do texto deixar claro que buscamos abordar questões relativas ao loft com o intuito de discuti-las a partir de autores que julgamos essenciais na compreensão das mesmas. Cremos que mais importante que estabelecer um conjunto de respostas que poderão ecoar vazias num silêncio teórico, é propor perguntas que são passíveis de suscitar outros estudos. Tentamos trazer a tona diversos nódulos que coadunam numa problemática digna de reflexão: a habitação na contemporaneidade. Julgamos ser extremamente válida uma reflexão mais aguda sobre os pontos aqui levantados. Esperamos ter deixado interconexões em suspensão e apresentado uma das diversas possibilidades para a análise dessa trama contemporânea.

Discursar acerca do loft é, de certa maneira, estabelecer um diálogo entre diversas possibilidades. A moral burguesa redefiniu a concepção de "morar" ao instaurar uma habitação unifamiliar e, atropelando a complexidade das dinâmicas da história, cindiu o espaço privado em cômodos, que se tornaram microcosmos da experiência individual. A habitação contemporânea está fundada no princípio do cômodo e essa colocação nos permite dizer que o loft é uma nuance contemporânea que se apresenta como um porvir. Já está posto, mas não é regra, todavia é indício de uma habitação onde deságua esse indivíduo ensimesmado, próprio de uma modernidade em desfragmentação.

Assumimos no texto uma posição negativa em relação à existência de pós-modernidade na contemporaneidade, justificando esta postura na afirmação de que a contemporaneidade se define como um lócus essencialmente de transição, donde podemos perceber a 
emergência de um novo que ainda não se estabeleceu firmemente, porém percebemos, na mesma perspectiva, que esse novo se assenta profundamente em bases modernas, o que inviabiliza o atual como pós-moderno. Nesse espaço de transição, tudo parece estar em processo irreversível de sublimação, com fins a novas formatações, sendo que alguns desses processos já estão em estágios tão avançados que nossa produção teórica se vê insuficiente.

A família moderna, que gravitava pela órbita dos modelos nucleares, a partir da morte simbólica do pai, sob a perspectiva psicanalítica, está perdida na transição, sem saber ao certo o que é e qual sua função diante da suspensão em que os valores morais se encontram. A família tem de enfrentar uma árdua tarefa: a de negociar com o indivíduo que ela própria fomentou em seu futuro já póstumo. A família construiu um espaço que deu todas as condições para o surgimento da individualidade tal qual a que conhecemos hoje.

Prost (1992) mostra um interessante dado que é ilustrativo da crise que a própria família construiu: "Em Paris,... mais da metade dos lares é de pessoas solitárias." (p.80). A frase revela que na medida em que foi sendo legitimado um espaço individual, onde uma identidade singular podia ser cultuada no seio da vida privada, a dinâmica nuclear se viu ultrapassada. O indivíduo, enquanto categoria analítica tomou a frente da família. A crise na família é apenas uma faceta; mais um nódulo que está intimamente imbricado com a crise do espaço público como espaço de permanência que, por sua vez está condicionado a uma necessidade vital do Capital. O homem produzido nessa conjuntura é essencialmente um homem sem lugar.

O homem contemporâneo é o homem do desamparo; o homem minimalista que tem no não-lugar o seu único espaço. $\mathrm{O}$ homem contemporâneo está imerso na transição de tal modo que sua própria vida se constitui dessa mesma transição, em que qualquer compromisso que possua vínculos com alguma solidez de longo prazo deve ser visto como um pecado e, quem por este pecado é acometido está fadado ao inferno da imobilidade. Cabe perguntar então: onde mora esse homem sem lugar?

O homem que é produto desse retrato não poderia habitar um lugar que não fosse um reflexo da imagem de si próprio. É historicamente assim que se dá a habitação. O homem da solidão não precisa de muito mais do que um cômodo, mas não somente um cômodo, ele necessita urgentemente de um hiper-cômodo que comporte todas as suas necessidades.

O loft nada mais é do que a concretização deste hiper-cômodo; quando o indivíduo que ali se estabelece é marcado pela solidão (leiase uma solidão produzida por um sócius em transição) e simultaneamente pelo fetichismo da mercadoria, o que lhe resta é essa alternativa habitacional. É um hiper-cômodo na medida em que não é mais que um mega quarto com cozinha, banheiro e em alguns casos garagem que está a repelir de si o individuo que o habita. É hiper, pois está como bem aponta Baudrillard (1991), assentado numa hiperrealidade, destituída de referenciais, onde não há, definitivamente, simulação de algo original, porém simulacro. A cidade não pode mais oferecer tanto espaço, visto que cada vez mais, um corpo individual reclama por um espaço só. É preciso racionalizá-lo e dessa necessidade surgem estratégias de demolição. Como se está finalmente só, não é preciso paredes. Pois, dos laços sociais urgem apenas efemeridades e é preciso negar co-dependências. O loft é símbolo atual e pode muito bem ser um dos sintomas do mal-estar que assola o modus vivendi contemporâneo, um dos produtos do deslocamento do corpo, produto de um corpo destituído de lugar.

Em prol da liberdade de movimentos, da luminosidade natural, da flexibilidade das estruturas, foi construída uma casa sem paredes, uma casa sem possibilidade de vida 
íntima, uma casa que propicia vida às plantas ornamentais e ao impulso do deleite estético. O loft é um "prato cheio" para o homem que vive a máscara da liquidez.

O loft é o panóptico, mas não o é, é o panóptico às avessas, no loft a distinção entre o observado e o observador já não mais impera, não é factível falar em submissão óptica visto que todos os olhares estão sob a mesma perspectiva. Quem entra no loft é convidado ao desconforto de não conseguir se situar, no desconforto de ser presa fácil do olhar alheio, na sujeição constante de estar se expondo, restando assim, apenas uma alternativa: sair dali. A dinâmica do loft coloca tudo e todos em suspensão ininterrupta.

A cidade como a conhecemos deve sair; deve dar lugar urgentemente ao fluxo; a organização tradicional da família deve sair, deve dar vazão a famílias recombinadas; o pai deve sair, o erotismo do compartilhar a significação sexual deve sair dando lugar a um sexo narcísico que reclama do ato o valor da performance; o espaço público deve morrer e, no mesmo sentido, o cômodo deve sair, dando lugar ao hiper-cômodo, receptáculo dessas identidades em crise.

\section{Bruno Ricardo Vasconcelos}

Bacharel em Ciências Sociais. Mestre em Psicologia pela Universidade Federal de Uberlândia. - MG - Brasil. E-mail: brunofadiga@hotmail.com

\section{Caio César Souza Camargo Próchno}

Doutor em Psicologia Social pela Universidade de São Paulo, Pós-Doutor em Filosofia e Psicologia pela Universidade de Leipzig, Leipzig-Alemanha. Professor associado IV do Instituto de Psicologia da Universidade Federal de Uberlândia, Uberlândia - MG - Brasil.

E-mail: c.prochno@uol.com.br

\section{Luiz Carlos Avelino da Silva}

Doutor em Psicologia Escolar e do Desenvolvimento Humano pela Universidade de São Paulo. Professor adjunto IV do Instituto de Psicologia da Universidade Federal de Uberlândia, Uberlândia, - MG - Brasil. E-mail: avelinoluiz@hotmail.com

\section{Endereço para envio de correspondência:}

Rua Cruzeiro dos Peixotos, 59, apto. 203, Aparecida, Uberlândia-MG. CEP: 38400-608.

Recebido: 08/02/2011, 1aㅡ Reformulação: 26/03/2012 Aprovado: 15/10/2012.

Referências
Baudrillard, J. (1991). Simulacros e Simulação. Lisboa: Ed. Antropos.

Benjamin, W. (1985). Magia e Técnica, Arte e Política. São Paulo: Brasiliense.

Benjamin, W. (2009). As Passagens, Belo Horizonte: Editora UFMG.

Berman, M. (2008). Tudo que é sólido se desmancha no ar. São Paulo: Companhia das Letras.

Corbusier, L. (1998). Por uma arquitetura. São Paulo: Editora Perspectiva.

Foucault, M. (1999). Vigiar e Punir. Petrópolis, RJ: Ed. Vozes.

Freud, S. (1996). Três Ensaios sobre a Teoria da Sexualidade. In Edição Standard Brasileira das Obras Completas de Sigmund Freud. (Vol. VII), Rio de Janeiro: Ed. Imago. (Trabalho original publicado em 1905).

Giddens, A. (1991). As Conseqüências da Modernidade. São Paulo: Ed Unesp.

Goethe, J. (1999). Viagem à Itália. São Paulo: Companhia das Letras.
Jameson, F. (2002). Pós-Modernismo - A Lógica Cultural do Capitalismo Tardio. São Paulo: Ed. Ática.

Kierkegaard, S. (2010). Temor e Tremor. Lisboa: Ed. Relogio D'Agua.

Prost, A. (1992). Fronteiras e Espacos do Privado. In Historia da Vida Privada: da Primeira Guerra aos Nossos Dias. (vol.5). São Paulo: Companhia das Letras.

Sennett, R. (1998). O Declínio do Homem Público: as tiranias da intimidade. (L. A. Watanabe, trad.). São Paulo: Companhia das Letras.

Simmel, G. (2006). Questões Fundamentais da Sociologia - Indivíduo e Sociedade. Rio de Janeiro: Ed. Jorge Zahar. 